medRxiv preprint doi: https://doi.org/10.1101/2021.06.02.21257981; this version posted June 3, 2021. The copyright holder for this preprint

(which was not certified by peer review) is the author/funder, who has granted medRxiv a license to display the preprint in perpetuity.

It is made available under a CC-BY-ND 4.0 International license .

\title{
COVID-19 Sniffer Dog experimental training: which protocol and which implications
}

\section{for reliable identification?}

Silvia Angeletti ${ }^{*}$, Francesco Travaglino ${ }^{2}$, Silvia Spoto ${ }^{3}$, Maria Chiara Pascarella ${ }^{2}$, Giorgia Mansi $^{2}$, Marina De Cesaris ${ }^{1}$, Silvia Sartea ${ }^{4}$, Marta Giovanetti ${ }^{5}$, Marta Fogolari1 ${ }^{1}$ Davide Plescia $^{6}$, Massimiliano Macera6 ${ }^{6}$ Raffaele Antonelli Incalzi ${ }^{7}$, Massimo Ciccozzi ${ }^{8}$

${ }^{1}$ Unit of Clinical Laboratory Science, University Campus Bio-Medico of Rome, Rome, Italy 2Emergency Department, University Campus Bio-Medico of Rome, Rome, Italy.

${ }^{3}$ Diagnostic and Therapeutic Medicine Department, University Campus Bio-Medico of Rome, Italy.

${ }^{4}$ Head of the Drive In Area, University Campus Bio-Medico of Rome, Rome, Italy.

${ }^{5}$ Laboratório de Flavivírus, Instituto Oswaldo Cruz, Fundação Oswaldo Cruz, Rio de Janeiro, Brazil

${ }^{6}$ K9 Unit SecurityDogs, NGS Private Security Company.

${ }^{7}$ Gerontology Unit, Campus Bio Medico University and Teaching Hospital, Rome, Italy

8 Unit of Medical Statistics and Molecular Epidemiology, University Campus Bio-Medico of Rome, Italy.

\footnotetext{
*Corresponding Author

Unit of Clinical Laboratory Science, University Campus Bio-Medico of Rome, Via Alvaro del Portillo 200

00128 Rome, Italy

$++3906224511461$

s.angeletti@unicampus.it
} 
medRxiv preprint doi: https://doi.org/10.1101/2021.06.02.21257981; this version posted June 3, 2021. The copyright holder for this preprint

(which was not certified by peer review) is the author/funder, who has granted medRxiv a license to display the preprint in perpetuity.

It is made available under a CC-BY-ND 4.0 International license .

\section{Abstract}

The introduction of trained sniffer dogs for COVID-19 disease detection could be an opportunity, as previously described for other diseases. Dogs could be trained to detect volatile organic compounds (VOCs), the whiff of COVDI-19 disease. Dogs involved in the study were three one male and two females from different breeds, Black German Shepherd, German Shepherd and Dutch Shepherd. The training was performed using sweat samples from COVID-19 positive apteints and from covid-19 free patients admitted at the University Hospital Campus Bio-medico of Rome. Gauze with sweat were collected in glass jar with metal top and put in metal boxes used for dog training. The dog training protocol was performed in two phase: the olfactory conditioning and the olfactory discrimintaion research. The training palnning was focused on the switch moment for the sniffer dog, the moment when the dog was able to identify VOCs specific for COVID-19 disease. At this time the dog was able to identify VOCs specific for COVID-19 disease with significant reliability, in terms of number of correct versus uncorrect $(\mathrm{p}<0.0001)$ reporting. In conclusion, this protocol could provide a useful tool for sniffer dogs training and their introduction in mass screening context, cheaper and faster than a conventional testing method.

Key words: Sniffer's dog; COVID-19; VOCs; dog training 
medRxiv preprint doi: https://doi.org/10.1101/2021.06.02.21257981; this version posted June 3, 2021. The copyright holder for this preprint

\section{INTRODUCTION}

The dog olfactory system with the olfactory mucosa of the nasal cavity have been largely studied for its unique charactersitic consisting in the presence of basal cells providing the regular regeneration of olfactory sensory neurons (OSNs) ${ }^{1}$ and for its abundance of olfactory recepetor reaching about 200 million. ${ }^{2,18}$ The dogs olfactory properties have been largely employed for the reaserach and detection of explosive substances or dead bodies, as Dog support units (DSUs) in police, army and civil protection divisions, in harbours and airport, in private security agency.

The use of sniffer dogs in medical settings can be dated back to 1989 and since then many other applications have been described, such as breast and lung cancers with percentage of detection rate ranging from $88 \%$ to $99 \%^{4}$ malaria disease with DR of about $82 \% 5$ and viral or bacterial infections with DR from $77 \%$ to $92.6 \%$

Several volatile organic compounds (VOCs) accounts for the odour released by expiration phase of breathing, skin emanation, urine and breath vapors, saliva and pathological conditions. These odours depends on biochemical modification occurring in the body with the consequent release of these specific compounds that are volatile ${ }^{9}$. The metabolic changes occurring in the body in presence of specific conditions such as inflammation, infections or neoplastic disease can be recognised by the dogs that are provided by a powerful olfactory apparatus if adequately trained to the detection of the VOCs. ${ }^{10}$

The same approach could be used for COVID-19 detection, as described in previous studies. ${ }^{11-14}$ The VOCs could be useful in clinical diagnosis od different disease inclusding bacterial and viral infections as SARS-CoV-2 causing COVID-19interstizial bilateral pneumonia11-14. In a recent study, dogs professionally trained were evalutaed for glucose 
medRxiv preprint doi: https://doi.org/10.1101/2021.06.02.21257981; this version posted June 3, 2021. The copyright holder for this preprint

levels detection in patients with diabetes. This study suggested that dogs after adequate training have the ability to detect hypo and hyperglycemic conditions. ${ }^{15}$

VOCS detection trained dogs could provide early detection of SARSCov-2 infected patients at low cost. The trained dog has the ability to screen more than 200 individuals per hour, enough to allow mass screening at airports, stadium, or in case of crowded events where the virus transmission control by asymptyomatic individuals is fundamental. This is in agreement with World Health Organization (WHO) recommendation about mass screening and its application also in low-income countries where the use of sophisticated and expensive screening tools could be limiting.

The study aims to evaluate the sniffer dogs ability to discriminate VOCs emanated by skin in course of COVID-19 disease, demonstrating that this disease is characterized by a specific odour and that dogs are able to indentify it efficiently and fastly.

\section{MATERIALS and METHODS}

2.1 Experimental design. The training planning was developed involving dogs from different breeds. Dogs involved in the study were from different working dog breeds, since their features are useful to standardize the characteristics, the management and the training coherence, to the advantage of more homogeneity in results recording. The intention was to concentrate the experiment on high quality rather than on great number of dogs. Infact, dogs were selected for their specific talents suitable to this kind of experimental design such as temperament, docility and resistance.

Covid-19 conditioned dogs, once involved in the study, will be recoverted to other activities of safety and security, if necessary or at the end of the pandemic, to guarantee 
medRxiv preprint doi: https://doi.org/10.1101/2021.06.02.21257981; this version posted June 3, 2021. The copyright holder for this preprint

the service continuity and mental and physical dogs health in the future. The study was approved by the Local Ethic Committee of University campus Bio-Medico of Rome (PAR

\subsection{OSS)}

The dogs training plan was divided in two steps: first step of "specific conditioning" to Covid-19 VOCs, consisting in the association of the odour reserch and consequent reporting. This critical and fundamental step is developed using several sweat samples from patients admitted to the Covid Center of the University Hospital Campus BioMedico of Rome, for Covid-19 disease. The second step of "olfactory discrimination research" consisited in the discrimination between the COVID-19 odour of interest and everything else that has to be extinguished. At this aim, the discrimination was performed between a box containing underarm sweat collected on gauze from Covid-19 positive patients, a box containing underarm sweat collected on gauze from Covid-19 negative patients, a box containing blank gauze and an empty box. The different boxes were randomly positioned in a line-up from a minimum of four possibilities upwards.

The training involved the repetion of different experimental sessions in line-up to fix more an more the VOCs in the olfactory memory of dogs.

\subsection{Sniffer dogs' characteristics}

Dogs involved in the study were three belonging to the SecurityDogs a brand of NGS srl. Security company (Italy) one male and two females from three different breeds: Black German Shepherd, German Shepherd and Dutch Shepherd. The demographic characteristics of dogs are reported in Table 1.

\subsection{Materials used for sweat samples collection and training}

Gauze was the elective support chosen for sweat collection, for its common distribution and consequent easy availability. The gauze used belong to Class IIa surgical device for its 
medRxiv preprint doi: https://doi.org/10.1101/2021.06.02.21257981; this version posted June 3, 2021. The copyright holder for this preprint

specific characteristics to be sterile, $100 \%$ cotton, latex and phtalate free (Figure 1A). Gauze with sweat were collected in glass jar with metal top (Figure 1B). The sniffer stand used for olfactory conditioning of dogs and the detection boxes used for the line-up are made of inhert materials to avoid plastics or adhesive materials that could be confoundent for the dogs'sniff. In each phase of dog training cross-contamination is avoided from sweat collection, storage, transport to training procedure. Training tools are projected to garantee that sweat samples never come in direct contact with dogs and tools are carefully sanitized at the end of each training session.

\subsection{Sweat samples collection procedure}

Skin sweat samples from patients with Covid-19 disease are collected at the Covid Center of the University Hospital Campus Bio-medico of Rome, while skin sweat samples from patients without Covid-19 disease collceted at the Internal Medicine Department of the University Hospital Campus Bio-medico of Rome. The demographic and clinical chracateristics of patients enrolled in the study are reported in Table 2. .Samples are anonimous identified and data registered on a database accessible only to the Principal Investigator of the study. Sweat samples are collected by patients with the assistance of the healthcare staff (physician or nusery) instructing them about the procedure, after informed consent has been recovered. This consists of self-collection by inserting gauze in the underarms, one for side, and mantaining in place for five minutes. After this, patients put both gauzes in the same glass can closed by the metal top and give it to the haelthcare staff that provides to the storage in a double bag for biological samples collection that can be delivered ouside the covid center to the Laboratory Division Glass can with sweat samples are delivered to the dog's training space adhibited within the Drive-in campus test area of the University Hospital campus Bio-Medico of Rome within two hours from collection. If 
medRxiv preprint doi: https://doi.org/10.1101/2021.06.02.21257981; this version posted June 3, 2021. The copyright holder for this preprint

(which was not certified by peer review) is the author/funder, who has granted medRxiv a license to display the preprint in perpetuity.

It is made available under a CC-BY-ND 4.0 International license .

training is delayed samples are stored in refrigerate controlled tempertaure at $4^{\circ} \mathrm{C}$ for a maximum of 24 hours.

\subsection{Dog training description}

During training all operations of samples managment are performed by healthcare staff adequately equipped with personal protective equipment (PPE) including single-use water-repellent lab coats to avoid, FFP3 disposable mask, water-repellent cover shoes, nitrile gloves and face shield. The same PPE are also used by the dog trainers in any phase of the training. Dogs are equipped with working dog equipment including dedicated collars and gears daily sanitized.

Training is performed indoor in a dedicated and well equipped space conisiting in a container located within the Drive In Covid test area of the University Hopsital Campus Bio-medico of Rome. Local temperature is controlled and manitained within a temperature range of $20-25{ }^{\circ} \mathrm{C}$ to minimize influence on the experimental assay. The same temperature range is checked and requested also for sweat samples used for dog's training.

Sweat samples collected in the glass jar after removal of the metal top are put inside the metal boxes used for line-up set-up and placed for 5 minutes before test start, time required for trace "ageing". After this interval time, the sweat sample can be sniffed by dogs and the test begins. At the end of the test, lasting about 2 minutes and 30 seconds, boxes with the sweat sample are alternatively moved within the line-up and sanitized for dogs rotation.

During the specific conditioning to COVID-19 VOCs, an ad hoc designed sniffer stand has been used allowing the safe accomodation of the sweat sample and the comfortable 
medRxiv preprint doi: https://doi.org/10.1101/2021.06.02.21257981; this version posted June 3, 2021. The copyright holder for this preprint

positioning for the dog's trainer when he enforces the the correct behaviour of the dog by the clicker and the material reward. In this phase is fundamental to use various sweat samples collected form different Covid-19 positive patients to fix in the olfactory memory of dog the presence of VOCs specific for Covid-19 within the vast range of odour emanations of the skin sweat. For the specific conditioning sniff repeats have been performed with positive reinforce by material rewards at each sniffing.

During the olfactory discrimination research the training aims at the detection of COVID19 VOCs towards dog has been conditioned and the discrimination from what it is not of interest, that has to be extinguished. In this phase, detection boxes with sweat samples from COVID-19 positive patients, sweat samples from COVID 19 negative patients, blank gauze and empty box have been used. Sweat samples hide from the beginning and never visible at the dogs are positioned randomly by the help of a randomic software.

The basis of this training phase is in the handler-dog K-9 unit, where the handler realizes that the dog is ready for the autonomous detection through the line-up and for the correct and univocal response by "sitting" or "lying down". This training phase is repeated from ten to tewenty times to fix the correct behaviour, depending by the dog's ability. At this phase follows the verification of the training procedure by dedicated trial sessions for each dog during which

The number of correct and uncorrect identification of COVID-19 positive sweat samples was recorded for further statistical analysis of data.

\subsection{Statistical analysis}

The percentage difference between correct and uncorrect identification registered in the verification of the protocol procedure for each dog was evaluated by $\square^{2}$ test for proportions. p value $<0.05$ was considered statistically significant. 
medRxiv preprint doi: https://doi.org/10.1101/2021.06.02.21257981; this version posted June 3, 2021. The copyright holder for this preprint

(which was not certified by peer review) is the author/funder, who has granted medRxiv a license to display the preprint in perpetuity.

It is made available under a CC-BY-ND 4.0 International license .

\subsection{De-briefing session}

Each training session has been video-recorded (as in the supplementary material) for further analysis during the de-briefing section performed at the end of each training session. Moreover, a specific report has been made for the training sessions tracing.

\subsection{Sanitizing}

Training site and training equipment were daily sanitized at the end of each training session, while waste disposal in special waste containers.

\subsection{Troubleshooting}

Sweat self-collection by inserting gauze in the underarms of the patients has to be carefully performed, as previously described to avoid any influence on training.

\section{RESULTS}

In April 2021 was completed the 4 weeks intensive training including 227 sessions and 700 tests with 92 different biological samples. These sessions aimed to identify the moment of switch for the dog. The switch is the time frame where the dog pass from a not relevant to a relevant percentage of correct reporting that has been fixed to $80 \%$ to be comparable to the gold standard diagnostic molecular and antigenic SARSCoV2 tests. From the switch, the training focused on fixing the correct behaviour otherwise the most reliable reporting by the dog, as much as possibile near to $100 \%$. The gradual progression of the dogs in these sessions until the switch moment has been schematized in Figure 2. Exactly, after assigning a coefficient of difficulty for each training session that is directly proprotional to the number of boxes in the line-up, it was observed that the dog Harlock from a minumim of $46 \%$ of correct reporting reached a maximum of $92 \%$, the dog Roma from a minimum of $63 \%$ arrived to $92 \%$ and the dog Idra from $53 \%$ pass to $100 \%$ of correct reporting. The 
medRxiv preprint doi: https://doi.org/10.1101/2021.06.02.21257981; this version posted June 3, 2021. The copyright holder for this preprint

occurred dog switch was evidenced in further trials sessions for each dog, exactly 17 for Harlock, 20 for Roma and 23 for Idra as reported in Table 3. Harlock correctly identied the COVID-19 positive sweat samples in the line-up 15/17 (88\%), Roma 17/20 (85\%) and Idra 20/23 (87\%) times. The difference between the percentage of correct and uncorrect identifications was statistically significant $(\mathrm{p}<0.0001)$ (Table 1), confirming the switch obtained for each dog.

\section{DISCUSSION}

Usually the test used for a mass screening mass should be rapid, enough sensitive, easy to manage, cheap and not time-consuming. The use of olfactory dogs has been proposed as fast, reliable and not expensive tool at this aim. The most critical factor is to provide a training protocol for sniffer dogs that could be easy to perform and enough reliable. The protocl prposed in this study provided some causes for reflection about the understanding of the "switch" moment for the dog. This moment corresponds to the time where the dog pass from a not relevant to a relevant percentage of correct reporting o be comparable to the gold standard diagnostic SARSCoV2 tests. In this study, data on the switch have been collected and the occurred dog switch evidenced in further trials sessions for each dog, with promising results in terms of sensitivity and specificty. Now the dog is ready for the mass screening in real-life. Overall, the proposed protocol, with focus on the switch moment, Could represent a valid support for sniffer dogs training replication in any setting.

The application of the proposed protocol for COVD-19 dog alert by sniffing axillary sweat samples, confirmed the ability of dogs, after specific training to detect COVID-19 VOCs. This approach provides a promising tool for COVID-19 mass screening at airports, 
stadium, or in case of crowded events where the virus transmission control by asymptyomatic individuals is fundamental in puclic health. After this first step, future perspectives will include training of further dogs using odor-less supports for skin emanation collection, the comparison between sniffer dogs ability and molecular RT-PCR gold test for Covid-19 diagnosis in different settings as the Drive In and the use of SARSCoV2 proteins for dogs training to direct viral particles instead of VOCs from sweat samples.

Conflict of interest: The authors declare that there are no conflict of interests.

Authors Contributions: Silvia Angeletti, Massimo Ciccozzi: study design, data analysis and study supervision; Francesco Travaglino, Silvia Spoto, Maria Chiara Pascarella, Giorgia Mansi and Raffaele Antonelli Incalzi patient clinical diagnosis and sweat samples collection; Marina De Cesaris, Marta Fogolari: Covid-19 laboratory test; Marta Giovanetti: data analysis; Silvia Sartea: Logistic at the Drive in Area; Davide Plescia and Massimiliano Macera: study design and dog training. All Authors contributed to the manuscript preparation 
medRxiv preprint doi: https://doi.org/10.1101/2021.06.02.21257981; this version posted June 3, 2021. The copyright holder for this preprint

(which was not certified by peer review) is the author/funder, who has granted medRxiv a license to display the preprint in perpetuity.

It is made available under a CC-BY-ND 4.0 International license .

\section{REFERENCES}

1. Graziadei PPC, Monti Graziadei G. Continuous Nerve Cell Renewal in the Olfactory

System. In: Jacobson M. (eds) Development of Sensory Systems. Handbook of Sensory

Physiology. 1978;9. Springer, Berlin, Heidelberg.

2. Lippi G, Cervellin G, Medicine L. Canine olfactory detection of cancer versus laboratory testing: myth or opportunity? Clin Chem Lab Med. 2012;50(3):435-439.

3. Lesniak A, Walczak M, Jezierski T, Sacharczuk M, Gawkowski M, Jaszczak KJ. Canine olfactory receptor gene polymorphism and its relation to odor detection performance by sniffer dogs. J Hered. 2008;99(5):518-527.

4. McCulloch M, Jezierski T, Broffmann M, Hubbard A, Turner K, Janecki T. Diagnostic accuracy of canine scent detection in early- and late-stage lung and breast cancers. Integr Cancer Ther. 2006;5(1):30-39.

5. Guest C, Pinder M, Doggett M, Squires C, Affara M, Kandeh B, et al. Trained dogs identify people with malaria parasites by their odour. Lancet Infect Dis. 2019;19(6):578-580.

6. Taylor MT, McCready J, Broukhanki G, Kirpalaney S, Haydon L, Powis J. Using dog scent detection as a point-of-care tool to identify toxigenic clostridium difficile in stool. Open Forum Infect Dis. 2018;5(8):1-4.

7. Angle C, Waggoner LP, Ferrando A, Haney P, Passler T. Canine detection of the volatilome: a review of implications for pathogen and disease detection. Front Vet Sci. 2016;3:1-7.

8. Angle TC, Passler T, Waggoner PL, Fischer TD, Rogers B, Galik PK, Maxwell HS. Realtime detection of a virus using detection dogs. Front Vet Sci. 2016;2:79. 
medRxiv preprint doi: https://doi.org/10.1101/2021.06.02.21257981; this version posted June 3, 2021. The copyright holder for this preprint (which was not certified by peer review) is the author/funder, who has granted medRxiv a license to display the preprint in perpetuity. It is made available under a CC-BY-ND 4.0 International license .

9. Amann A, de Lacy Costello B, Miekisch W, Schubert J, Buszewski B, Pleil J, Ratcliffe

N, Risby T. The human volatilome: volatile organic compounds (VOCs) in exhaled breath, skin emanations, urine, feces and saliva. J Breath Res. 2014;8(3):034001.

10. Wells DL. Dogs as a diagnostic tool for ill health in humans. Altern Ther Health Med. 2012;18(2):12-17.

11.Helse H. Can dogs smell COVID? Here's what the science says. Nature. 2020;587(7835):530-531.

12. Jendrny P, Schulz C, Twele F, Meller S, von Köckritz-Blickwede M, Osterhaus ADME, et al. Scent dog identification of samples from COVID-19 patients - a pilot study. BMC Infect Dis. 2020;20(1):536.

13. Grandjean D, Sarkis R, Lecoq-Julien C, Benard A, Roger V1, Levesque E, BernesLuciani E, et al. Can the detection dog alert on COVID-19 positive persons by sniffing axillary sweat samples? A proof-of-concept study. PLoSONE 2020;15(12):e0243122.

14. Eskandari E, Marzaleh MA, Roudgari H, Farahani RH, Nezami-Asl A, Laripour R, Aliyazdi H, et al. Sniffer dogs as a screening/diagnostic tool for COVID-19: a proof of concept study. BMC Infect Dis. 2021;21(1):243.

15. Petry NM, Wagner JA, Rash CG, Hood KK. Perceptions about professionally and nonprofessionally trained hypoglycemia detection dogs. Diabetes Res Clin Pract. 2015;109(2):389-96. 
medRxiv preprint doi: https://doi.org/10.1101/2021.06.02.21257981; this version posted June 3, 2021. The copyright holder for this preprint (which was not certified by peer review) is the author/funder, who has granted medRxiv a license to display the preprint in perpetuity. It is made available under a CC-BY-ND 4.0 International license .

\section{Figure legends}

FIGURE 1 Gauze used for underarm sweat collection by patients (A). Glass jar with metal top used for gauze collection (B).

FIGURE 2 The gradual progression of the dogs until the switch moment (red cicle): percentage of correct identification normalized for the coefficient of difficulty (Yaxis) and number of trials (X axis). 

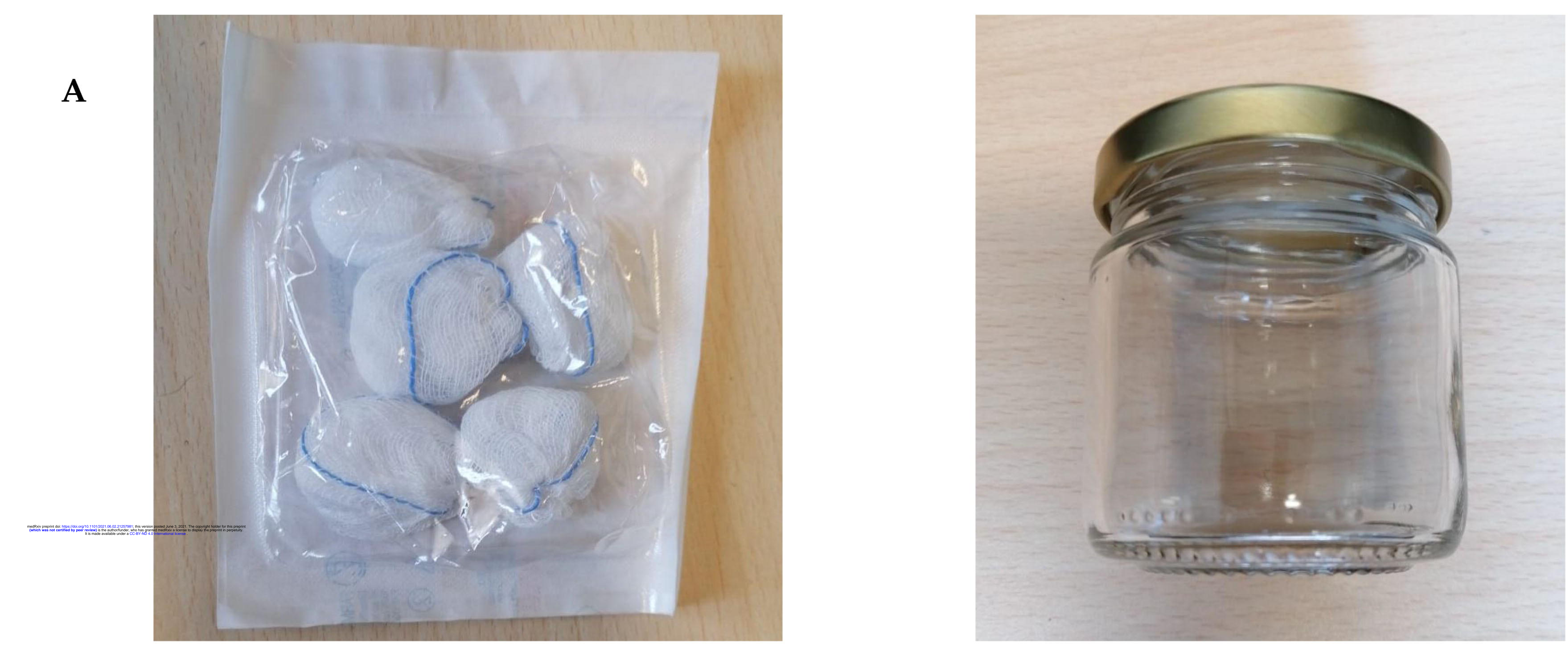

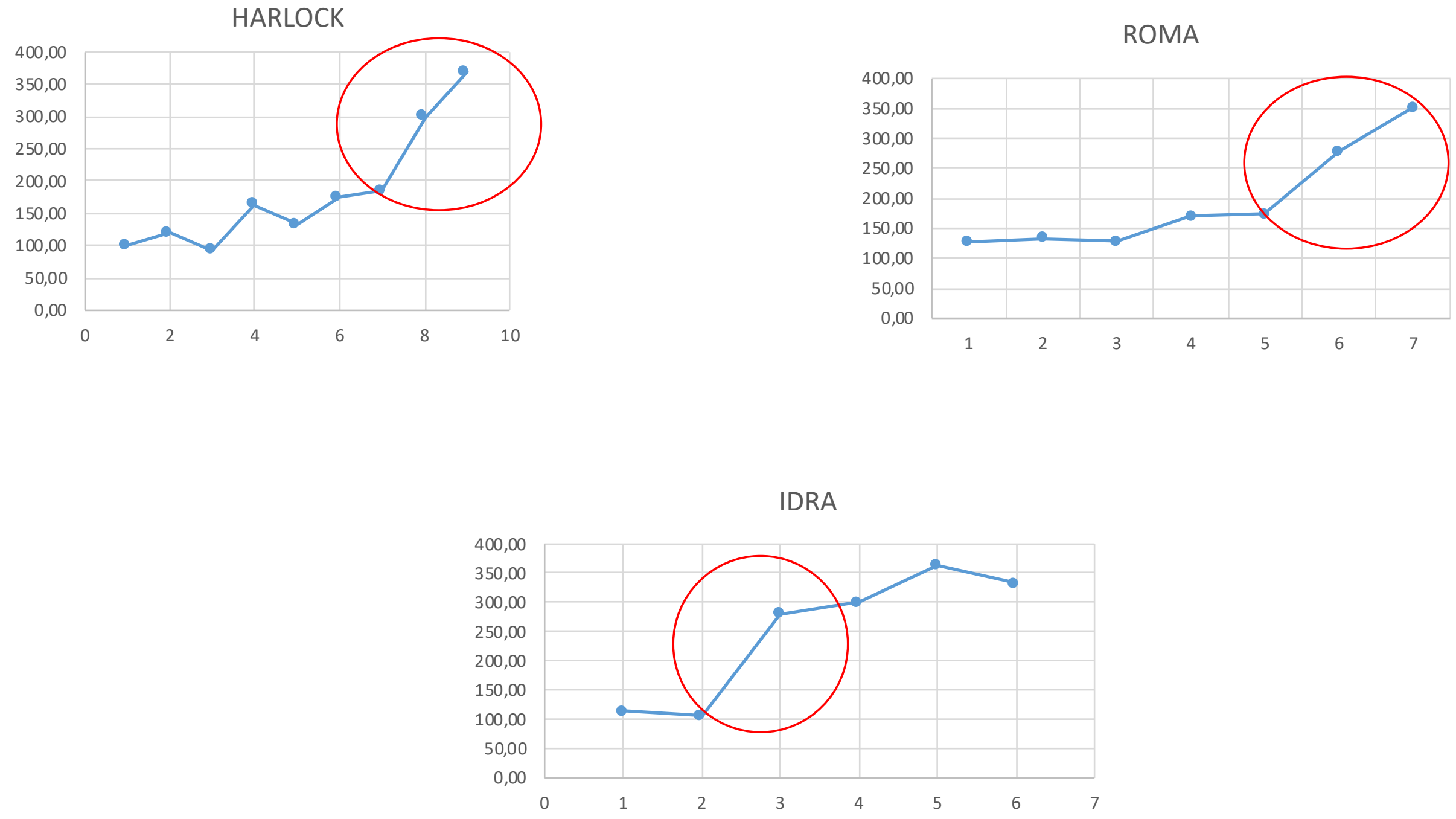
medRxiv preprint doi: https://doi.org/10.1101/2021.06.02.21257981; this version posted June 3, 2021. The copyright holder for this preprint (which was not certified by peer review) is the author/funder, who has granted medRxiv a license to display the preprint in perpetuity.

It is made available under a CC-BY-ND 4.0 International license .

Table 1. Demographic characteristics of dogs involved in the study protocol.

\begin{tabular}{|l|c|l|l|cc|}
\hline Dog's name & Age (year) & Gender & Specie & $\begin{array}{l}\text { Explosive } \\
\text { trained }\end{array}$ & substances \\
\hline HARLOCK & 3 & Male & Black German Shepherd & Yes \\
ROMA & 4 & Female & Dutch Shepherd & Yes \\
IDRA & 1 & Female & German Shepherd & No \\
\hline
\end{tabular}

Table 2. Demographic and clinical chracateristics of patients enrolled in the study.

\begin{tabular}{|l|l|l|}
\hline & $\begin{array}{l}\text { Positive COVID-19 patients } \\
\mathrm{n}=20\end{array}$ & $\begin{array}{l}\text { Negative COVID-19 patients } \\
\mathrm{n}=15\end{array}$ \\
\hline Mean Age (years) & 57.8 & 73.4 \\
\hline $\begin{array}{l}\text { Sex n (\%) } \\
\text { Male }\end{array}$ & $9(45)$ & $10(67)$ \\
Female & $11(55)$ & $5(33)$ \\
\hline Comorbidity n (\%) & $9(45)$ & $15(100)$ \\
Diabetes & $2(22)$ & 0 \\
High blood pressure & $6(66)$ & $11(73)$ \\
Cardiovascular disease & 0 & $11(73)$ \\
Obesity & $3(33)$ & 0 \\
Cancer & $3(33)$ & $6(40)$ \\
Ictus & $1(11)$ & 0 \\
COPD & 0 & $4(26)$ \\
Healthy n (\%) & $11(55)$ & 0 \\
\hline Diagnosis at admission & & \\
COVID-19 pneumonia & $20(100)$ & 0 \\
Pneumonia no Covid-19 & 0 & $6(40)$ \\
Cardiovascular disease & 0 & $3(20)$ \\
Ascites & 0 & $1(6.6)$ \\
Diverticulitis & 0 & $1(6.6)$ \\
Pleural effusion & 0 & $2(13)$ \\
Sepsis & 0 & $2(13)$ \\
\hline
\end{tabular}

Table 3. Number $\left(\mathrm{n}^{\circ}\right)$ and percentage $(\%)$ of total trials performed and correct and uncorrect identification by the dogs for the verification of the training protocol.

\begin{tabular}{|l|c|c|c|c|c|}
\hline Dog's name & Trial n. & $\begin{array}{c}\text { Correct } \mathbf{n}^{\circ} \\
\mathbf{( \% )}\end{array}$ & $\begin{array}{c}\text { Uncorrect n }^{\circ} \\
\mathbf{( \% )}\end{array}$ & ] $^{2}$ & p value \\
\hline HARLOCK & 17 & $15(88)$ & $2(12)$ & 19.06 & $<0.0001$ \\
ROMA & 20 & $17(85)$ & $3(15)$ & 19.11 & $<0.0001$ \\
IDRA & 23 & $20(87)$ & $3(13)$ & 24.64 & $<0.0001$ \\
\hline
\end{tabular}

